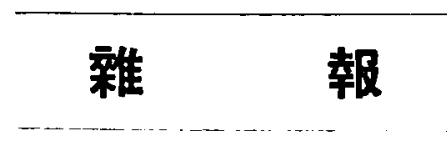

○人 事

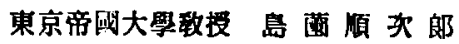

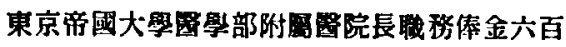
拾国下靤

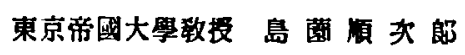

渴本俸二級俸

$$
(十=\text { 月+ス日) }
$$

從五位勳三等 尾崎文七郎

從五位卧司治

鈘正五位

(十ン月十六タ)

九州帝國大學数骎 赤 岩 八 郎

渴本偆二級偆

九州帝四大學致摱 皆 省 吾 渴本偆五級棒

$(t=日=+$ 日)

鐵道㹂 小栗三式

鐵道等二任

(十=月二十田日)

年俈六百六拾目下賜

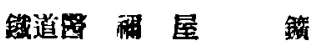

鐵道小栗三式

年俸貮干百六拾圆下晹

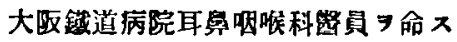

$(+=$ 月ニ+田日)

敍正六位

從六位動六等 大岩 博 雅

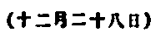

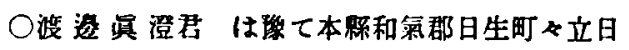
生病院長として勤䅂し居られしが今股剧項の黑濑 躍君の後任として压原病院長に就任せられたり

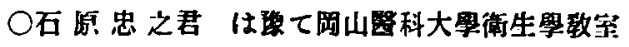
及积田內科教穿に於て研究中なりし同君は剧項の 源逞澄君の後任として日生病院長に就任せたれ たり
○荛田㮌一君多年傳染病研究所に於工研究中 なりし同君は昨冬满洲國新京興安大路满洲國御生 技術㟲に輬任せられたり

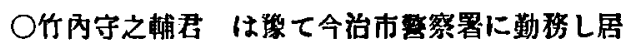

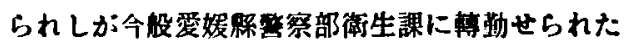
y

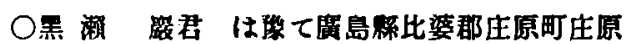
病院に勤䅂し居られしが今般同院を辟し神戶市須 磨區須磨寺町 2 丁日に於て開業せられたり

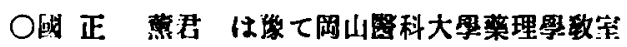
に於て研究中なりしが今般锌僟の上藏島䇣賀茂郡 廣村に於て開業せられたり

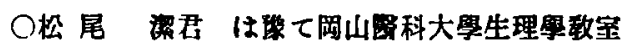
に於て研究中なりしが今四同教空を鲜し明石市上 水道町に於て開業せられたり

\section{$\odot$ 位授興}

小坂壽，中富和夫, 藤河武雄, 水野文次郎の 4 君

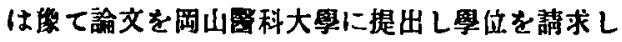
居られしが本月 2 日の敌摱曾を通過し本月23日 䀹學博士の學位を授興せられたり其の主渝文及び 考詥文は左の如し.

$$
\text { 小坂慗君 }
$$

主淪文

「モノョード酸施機能二及ポス作用

1. 「モノョード醋酸蛙骨筋機能二及ボス作 用（岡山醫科大學䯉文業府第 4 管第 4 號 二發表不)

2.「モノョード」酷酸八心施二對スル作用

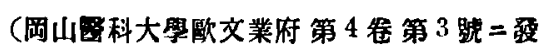
表不） 
噍

\section{考部文}

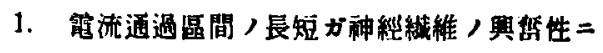

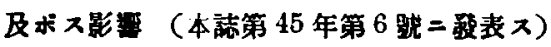

2. 興整性ト夫レフ支㭱スル物理化學的條件

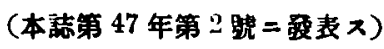

3. 夏期蛙筋，特異性二就テ（本誌第 47 年第 3 践二喥表. )

4. 冬眠中／䗆蝠，瓦斯代謝二及ボス珢獍溫度

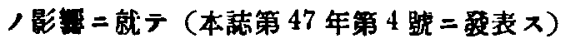

5. 細胞分裂促進線二開 $ス 几$ 研究（岡山国科 大學欧文業府第 4 管 4 踮二表

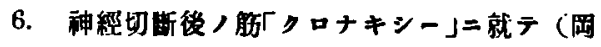

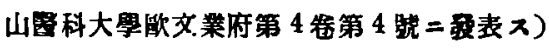

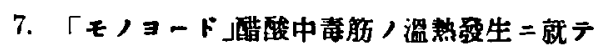
（林香苗共著）（風山然科大學吹文業府第 4

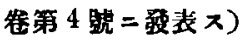

\section{中富和夫君}

主諭 文

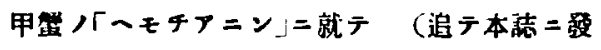
表 /

\section{考考論文}

1. 過敏定毒二閵スル研究（追テ本誌二报 , 定)

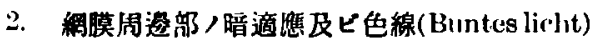

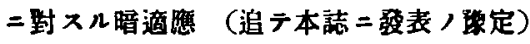

3. 伸展セル神經及ビ筋ノらロナキシー」就 テ（追テ本誌二諁表，踪定）

4. 神經，逆主幸二關ス几研究㭪透（追テ本 誌二表，棵定）

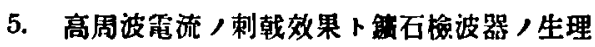

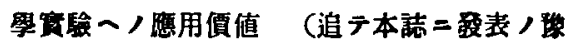
定)
主部文

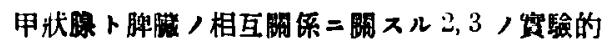
研究

1. 㧅若赤血球殊 $=$ 網狀赤血球及ビ赤血球沈

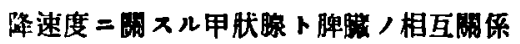
（本誌第 47 年第 5 躆二表 $ス ）$

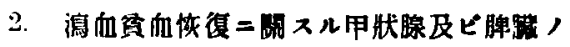

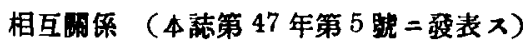

3. 異種赤血球／運命二關スル甲狀腺及ビ脾

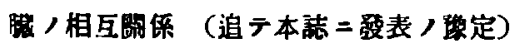

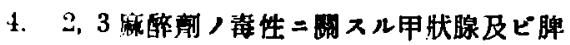

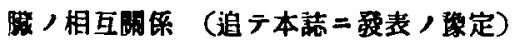

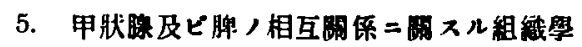
的研究 (追テ本誌二舞表，像定）

斑考論文

1. 超生體可染物賈保有赤血球，血液「カタラ

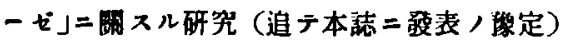

2. 結㤥性疾患，脾险食投興期間 $=$ 就テ (大

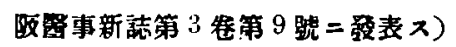

3.「トロトラスト」ニ依几血管据影ニ就テ（果 京贯事新誌第 2864 躆 =表表友)

4. 瓦斯蜂㔖織炎，定们二就二

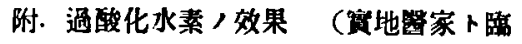

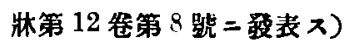

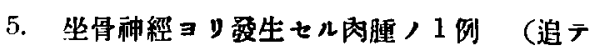

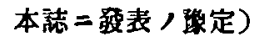

水野文次郎君

主論文

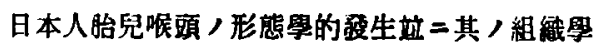

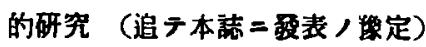

考論文

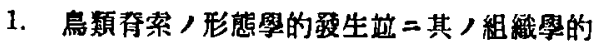
研究 


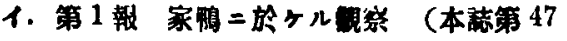
年第 5 影二被表 $ᄌ$ )

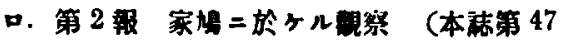
年第 6 䟽=表七y)

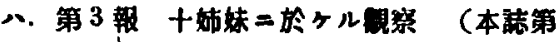
47 年第 9 晴二教表ス)

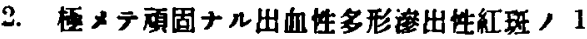

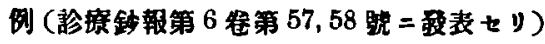

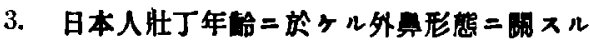
統斻的㨼

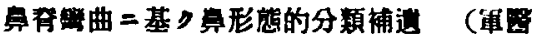

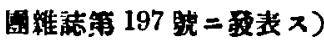

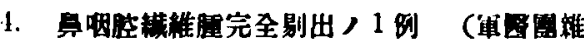
誌第 218 躆二段表入)

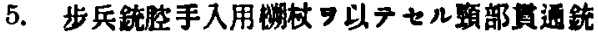

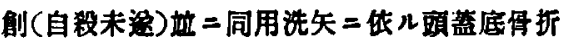

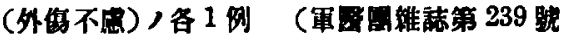
二垡表不)

6. Hirschsprung'sche Krankheit , 5 们

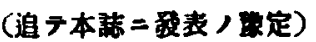

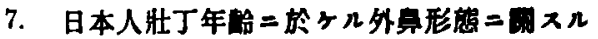

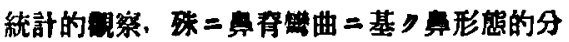

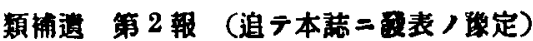

\section{○役員選藇}

昭和 11 年度の本曾役員投赫用緍は昨年 12 月踏雓 誌に綗込みあるを以て同紙を用ひて本年2月6日

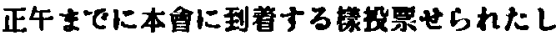

